\title{
Flow cytometric analysis to evaluate physiological alterations in herbicide-exposed Chlamydomonas moewusii cells
}

\author{
Raquel Prado, Carmen Rioboo, Concepción Herrero, Paula Suárez-Bregua, Ángeles Cid ${ }^{1}$
}

Ecotoxicology, March 2012, Volume 21, Issue 2, pp 409-420

DOI 10.1007/s10646-011-0801-3

\begin{abstract}
Investigation of herbicide toxicology in non-target aquatic primary producers such as microalgae is of great importance from an ecological point of view. In order to study the toxicity of the widely used herbicide paraquat on freshwater green microalga Chlamydomonas moewusii , physiological changes associated with $96 \mathrm{~h}$-exposures to this pollutant were monitored using flow cytometry (FCM) technique. Intracellular reactive oxygen species concentration, cytoplasmic membrane potential, metabolic activity and cell protein content were monitored to evaluate the toxicological impact of paraquat on algal physiology. Results showed that herbicide paraquat induced oxidative stress in C. moewusii cells, as it indicated the increase of both superoxide anion and hydrogen peroxide levels observed in non-chlorotic cells of cultures exposed to increasing herbicide concentrations. Furthermore, a progressive increase in the percentage of depolarised cells and a decrease in the metabolic activity level were observed in response to paraquat when non-chlorotic cells were analysed. Chlorotic cells were probably non-viable cells, based on the cytoplasmic membrane depolarisation, its metabolically nonactive state and its drastically reduced protein content. In view of the obtained results, we have concluded that a range of significant physiological alterations, detected by flow cytometry, occur when $C$. moewusii , an ubiquitous microalga in freshwater environments, is challenged with environmentally relevant concentrations of the herbicide paraquat.
\end{abstract}

\section{Keywords}

Microalga, Toxicity, Herbicide, Paraquat, Flow cytometry, Oxidative stress

\footnotetext{
${ }^{1}$ Laboratorio de Microbiología, Facultad de Ciencias, Universidad de A Coruña, Campus de A Zapateira s/n, 15008 A, Coruña, Spain
} 


\section{Introduction}

Many herbicides have high water solubility and low sorption coefficients, allowing rapid uptake into target plants. Such physicochemical properties also render them susceptible to off-site transfer into the aquatic environment, so that high herbicide concentrations could reach aquatic systems and become toxic for phototrophic microorganisms, such as microalgae, even without being the original target species for which the herbicide was designed (Deneer 2000; Warren et al. 2003). Therefore, pollution with herbicides must be considered as a potential risk for aquatic ecosystems, altering phototrophic species assemblages (Kish 2006; Seguin et al. 2001), as well as for the quality of drinking water (Katsumata et al. 2006), since some herbicides in use are known to be mutagenic, carcinogenic or teratogenic (Nguyen-Ngoc et al. 2009).

Microalgae are among the essential components of aquatic ecosystems, producing oxygen and organic substances on which most organisms, including fishes and invertebrates, are dependent. In this way, chemical effects on algae can directly affect the structure and function of an ecosystem resulting in oxygen depletion and decreased primary productivity. The effects on microalgae therefore are not only important for the organisms themselves, but also for other links in the food chain (Daam et al. 2009; De Lorenzo et al. 2002; Rioboo et al. 2007). It is thus essential to assess the effects of toxic compounds on non-target microalgal species and, considering that sensitivity to pollutants varies widely among these organisms, it is important to look for new and more sensitive species in order to obtain biological data to evaluate ecological risk.

Furthermore, developing convenient methods to detect contaminants based on the physiological response of organisms has become a major goal in ecotoxicological research. This is to provide an early warning of sublethal pollution (Eullaffroy and Vernet 2003). Monitoring of herbicides as pollutants in non-target environments is largely achieved through chemical analysis of a few key chemicals. However, regulatory agencies have recognized the need to complement these analytical chemical results with rapid and sensitive bioassays (Muller et al. 2008).

Standardised algal growth bioassays remain the preferred technique for assessment of phytotoxic effects in most ecotoxicological studies (van Wezel and van Vlaardingen 2004), but these tests provide bulk measurements which do not allow us to observe potential intercellular differences within the cellular population analysed. Moreover, results obtained do not offer information regarding a mode of toxic action. In that respect, flow cytometry (FCM) has been introduced as an alternative to traditional techniques for studying the response of microalgal cells exposed to different pollutants in toxicity bioassays (Cid et al. 1996; Franqueira et al. 2000).

FCM allows the rapid determination of a high number of cell functions by using a great variety of biochemically specific, non-toxic and fluorescent molecules in conditions close to the in vivo 
status in short-term exposures to high levels of light. Recently, fluorescent probes have been applied to physiological studies of algae and other microorganisms (Adler et al. 2007; Rioboo et al. 2009; Veal et al. 2000). In an ecotoxicological context, there are recent studies with microalgae as test organisms in which it was demonstrated that, although very rarely used in ecotoxicology, FCM combined with the use of different fluorochromes is a quick and convenient technique to assess toxic effects of pollutants that can generate information on the mode of action of contaminants (Adler et al. 2007; Jamers et al. 2009). However, the potential of this technique as a tool in microalgal toxicity bioassays has not yet been fully exploited.

Paraquat is one of the most widely used herbicides in the world for the control of broadleaf weeds in several crops due to its great efficiency and low cost (Fuerst and Vaughn 1990; Qian et al. 2009). In a previous study, we have observed, using FCM, that the exposure of the freshwater microalga Chlamydomonas moewusii to increasing paraquat concentrations, caused chlorosis in a concentrationdependent percentage of microalgal population, and we concluded that chlorotic cells were non-viable cells based on their reduced size and complexity and their inability to be stained with fluorescein diacetate (Prado et al. 2011).

Now, in the present work, we aim to study in depth the cell response of this microalgal species to median-term exposures to paraquat. For this reason, different staining protocols were optimised to assess the toxicological impact of this herbicide on different aspects related to microalgal physiology and biochemical composition, by means of FCM, which allowed us to separately analyse chlorotic and non-chlorotic cells. The importance of oxidative stress as a mechanism of paraquat toxicity has been demonstrated in studies with different organisms (Ananieva et al. 2004; Suntres 2002). Consequently, we decided to monitor the intracellular generation of reactive oxygen species (ROS): superoxide anion $\left(\mathrm{O}_{2}^{\circ}{ }^{\circ}\right)$ and hydrogen peroxide $\left(\mathrm{H}_{2} \mathrm{O}_{2}\right)$. Cytoplasmic membrane potential, esterase activity and protein content were also monitored by staining cells with different fluorochromes, taking into account the differentiation between chlorotic and non-chlorotic cells.

\section{Materials and methods}

\section{Microalgal cultures}

Chlamydomonas moewusii Gerloff (Chlamydomonadaceae) was obtained from the Culture Collection of Algae and Protozoa of Dunstaffnage Marine Laboratory (Scotland, UK) (strain CCAP 11/5B) and was maintained in sterile Bristol medium (Brown et al. 1967).

The inoculum for the assays was taken from a 3-day-old stock culture, with the aim of using cells growing in a logarithmic phase for all experiments. Cultures were grown in sterile $500 \mathrm{ml}$ Pyrex glass bottles containing $300 \mathrm{ml}$ of sterile medium. Initial cell density was $4 \times 10^{5}$ cells ml$^{-1}$. Microalgal cultures were maintained at $18 \pm 1^{\circ} \mathrm{C}$, illuminated with a photon flux of $70 \mu \mathrm{mol} \mathrm{m}^{-2} \mathrm{~s}^{-}$ ${ }^{1}$ under a dark:light cycle of 12:12 $\mathrm{h}$ and continuously aerated, over $96 \mathrm{~h}$. 
Paraquat was added to the growth media to create a range of different exposure concentrations related to the $\mathrm{EC}_{50}$ values obtained previously (Prado et al. 2009b), i.e. $50 \mathrm{nM}$ (lower than the $\mathrm{EC}_{50}$ ), 100 and $150 \mathrm{nM}$ (around the $\mathrm{EC}_{50}$ values), and $200 \mathrm{nM}$ (higher than the $\mathrm{EC}_{50}$ ). Paraquat stock solution ( $1 \mathrm{mM}$ ) was prepared by dissolving granulated herbicide (Sigma; MW: 257.2) in distilled and sterilized water. Control cultures were also included, to whichno paraquat was added. All cultures were carried out intriplicate.

Actual paraquat concentrations in culture samples collected at the beginning and at the end of the $96 \mathrm{~h}$ exposure period were determined by a HPLC-MS protocol (Castro et al. 1999).

Flow cytometric analysis of microalgal cells

Flow cytometric analysis of $C$. moewusii cells was performed in a Coulter Epics XL4 flow cytometer (Beckman Coulter Inc., Fullerton, CA, USA) equipped with an argonion excitation laser (488 nm), detectors of forward (FS)and side (SS) light scatter and four fluorescence detectors corresponding to four different wavelength intervals: 505-550 nm (FL1), 550-600 nm (FL2), 600-645 nm (FL3) and >645 nm (FL4). Forward scatter and red chlorophyll fluorescence histograms were used to characterize the microalgal population, setting gating levels in order to exclude non-microalgal particles. For each cytometric parameter investigated, at least $10^{4}$ gated cells were analysed per culture and fluorescence measurements were obtained in a logarithmic scale. Data were collected using listmode files and statistically analysed using EXPO32 ADC software (Beckman Coulter Inc.).

The concentration, duration of labelling and intensity of staining was optimised for each fluorescent marker in order to create a staining protocol with the least concentration possible as well as the shortest labelling time. The lowest fluorochrome concentration and shortest incubation time were chosen in order to obtain significant and stable staining of cells without toxicity being developed.

Oxidative stress measurement: determination of intracellular levels of reactive oxygen species (ROS)

Oxidative stress in C. moewusii cells was evaluated, after $96 \mathrm{~h}$ of paraquat exposure, based on FCM determinations of intracellular levels of superoxide anion radical $\left(\mathrm{O}_{2}{ }^{*}\right)$ and hydrogen peroxide $\left(\mathrm{H}_{2} \mathrm{O}_{2}\right)$, using the fluorochromes hydroethidine $(\mathrm{HE})$ and dihydrorhodamine 123 (DHR123), respectively.

Hydroethidine $(\mathrm{HE})$ or dihydroethidium has been widely used to detect intracellular $\mathrm{O}_{2}{ }^{--}$in animal cells (Zhao et al. 2003). It can enter the cell where it is selectively oxidised by superoxides (Benov et al. 1998) to form a DNA-binding fluorophore, giving a fluorescence signal, with a maximum emission at $605 \mathrm{~nm}$, that can be quantified by FCM. A HE (SigmaAldrich Co.) stock solution was prepared in dimethylsulfoxide (DMSO) at a final concentration of $3.17 \mathrm{mM}$, and stored at $-20^{\circ} \mathrm{C}$. Cell suspensions $\left(2 \times 10^{5}\right.$ cells $\left.\mathrm{ml}^{-1}\right)$ were incubated with this 
fluorochrome at a final concentration of $15.85 \mu \mathrm{M}$ at room temperature for $30 \mathrm{~min}$. Fluorescence emission from oxidised products of HE was collected by the FL3 detector (600-645 nm) of the cytometer used.

Dyhydrorhodamine 123 (DHR123) was shown to be specifically responsive to $\mathrm{H}_{2} \mathrm{O}_{2}$ (Henderson and Chappell 1993; Qin et al. 2008; Walrand et al. 2003). This dye passively diffuses across cell membranes and, once inside the cell, it can be oxidised, mainly by $\mathrm{H} 2 \mathrm{O} 2$, in a slow reaction unless catalysed by an enzyme with peroxidase activity, and secondarily by peroxynitrite anion, to form cationic rhodamine 123 (Dikshit and Sharma 2001). This is a fluorescent compound which localises in the mitochondria emitting a bright fluorescent signal with a maximum emission at $529 \mathrm{~nm}$. A DHR123 (Sigma-Aldrich Co.) stock solution was prepared in DMSO at a final concentration of $5.77 \mathrm{mM}$, and stored at $-20^{\circ} \mathrm{C}$. Cell suspensions $\left(2 \times 10^{5} \mathrm{cells} \mathrm{m}^{-1}\right)$ were incubated with the fluorochrome at a final concentration of $28.87 \mu \mathrm{M}$ at room temperature for 60 min. Fluorescence emission from oxidized products of DHR123 was collected by the FL1 detector (505-550 nm).

In each case, aliquots of untreated and treated samples remained unstained for autofluorescence measurements, so that fluorescence values obtained after staining cells were corrected by subtracting their autofluorescence. In order to avoid the variability due to differences in cell size, which have been reported for cultures of this microalga exposed to paraquat (Prado et al. 2011), fluorescence were corrected by cell size estimated using the forward scatter light (FS). For both fluorochromes, staining protocol was validated incubating stained cells with $\mathrm{H}_{2} \mathrm{O}_{2}$ at a final concentration of $5 \mathrm{mM}$ for $10 \mathrm{~min}$, as a positive control.

Cytoplasmic membrane potential assessment

In the present work, cytoplasmic membrane potential of $C$. moewusii cells was monitored using a slow-response potentiometric probe, characterised by showing high fluorescence dynamics upon changes in membrane potential by its Nernstian distribution between the inside and outside of the cell (Ehrenberg et al. 1988; Plásek and Sigler 1996).

We used the lipophilic anionic oxonol dye bis-(1,3-dibutylbarbituric acid) trimethine oxonol $\left(\operatorname{DiBAC}_{4}(3)\right)$, which undergoes a potential-dependent distribution between the cytoplasm and the extracellular medium in eukaryotic cells. Once the cells are equilibrated with $\operatorname{DiBAC}_{4}(3)$, cytoplasmic membrane depolarisation will be reflected in an increased intracellular anionic dye concentration, i.e. by accumulation of dye in the cells, whilst decreased accumulation will reflect hyperpolarisation (Rabinovitch and June 1990). Upon depolarisation of the cellular membrane, the negatively charged oxonol moves from the extracellular aqueous environment, where it exhibits low fluorescence, into the cytosol, where it is bound to intracellular proteins and membranes and its fluorescence intensity is enhanced (Wolff et al. 2003).

Aliquots of $2 \times 10^{5}$ cells $\mathrm{ml}^{-1}$ were stained with $\mathrm{DiBAC}_{4}(3)$ (Sigma Aldrich Co.) at a final concentration of $0.97 \mu \mathrm{M}$ from a $0.97 \mathrm{mM}$ stock solution in $\mathrm{DMSO}$, incubated at room 
temperature in darkness for $10 \mathrm{~min}$. The green fluorescent emission of this compound, with a maximum at $516 \mathrm{~nm}$, was collected by the FL1 detector $(505-550 \mathrm{~nm})$. Aliquots of untreated and treated samples remained unstained for autofluorescence investigations in order to avoid false positives in $\operatorname{DiBAC}_{4}(3)$ emission spectra as a consequence of changes in the emission spectra of damaged photosynthetic systems (Caux et al. 1996). The utility of this membrane potential dye in our model system was validated by analysing cells for acute changes in their cytoplasmic membrane potential. Microalgal cells stained with $\operatorname{DiBAC}_{4}(3)$ were depolarised, to obtain a positive control, by increasing concentrations of extracellular $\mathrm{KCl}$ in the presence of digitonin (final concentration of $32.54 \mu \mathrm{M}$ during $15 \mathrm{~min}$ ). This is a weak, non-ionic detergent that selectively renders the plasma membrane permeable whilst the nuclear envelope and other major membrane organelles remain intact (Kuin et al. 2000).

Metabolic activity determination: kinetic assay of FDA-dependent fluorescence generation

Metabolic activity was assessed using a fluorescein diacetate-based cell esterase activity assay, which has been reported as a sensitive and rapid technique to assess phytoplankton metabolic activity (Dorsey et al. 1989; Jochem 1999; Prado et al. 2009a). Fluorescein diacetate (FDA) is a lipophilic, non-fluorescent substance which enters the cells freely and, once inside the cell, its acetate residues are cleaved off by non-specific esterases, making the polar hydrophilic fluorescent product fluorescein, which is retained by cells with intact plasma membrane, proportionally to the cell esterase activity. The amount of fluorescence will therefore increase over time depending on the metabolic activity of these enzymes.

In the present work we used a kinetic approach to the FDA assay (in fluxo analysis) to examine the effect of paraquat on the fluorescein fluorescence intensity generated in $C$. moewusii cells, indicative of the metabolic activity level (Dorsey et al. 1989; Gilbert et al. 1992), taking into account only viable/metabolically active cells. Kinetic measurements of FDA-dependent fluorescence generation were performed recording the increase of green fluorescence, collected by FL1 detector (505-550 nm), after FDA addition depending on time, adapting the protocol developed by Lage et al. (2001) to this microalga.

The final FDA (Sigma-Aldrich Co.) concentration used to stain cell suspensions $\left(2 \times 10^{5}\right.$ cells $\mathrm{ml}^{-}$ ${ }^{1}$ ) was $0.24 \mu \mathrm{M}$, obtained from a stock solution prepared at a concentration of $0.24 \mathrm{mM}$ in DMSO and stored at $-20^{\circ} \mathrm{C}$. Acquisition protocol was as follows: a baseline green fluorescence of unstained cells was recorded for approximately $30 \mathrm{~s}$, then FDA was added to the cell suspension and acquisition of the green fluorescence was resumed for approximately $5 \mathrm{~min}$ (time enough to stabilise the generated fluorescence). Then, FDA-dependent fluorescence generation rates (directly related with metabolic activity level, and expressed as fluorescence arbitrary units per minute), were calculated by regression analysis of mean fluorescence values over time, obtained defining one-channel wide, rectangular regions over the time axis for each kinetic plot (Juan et al. 1994). Because FDA-derived fluorescence emission can be altered by 
changes in cell volume (Agustí et al. 1998), fluorescence values obtained were normalized to cell size values estimated using FS.

Thermal death by microwave heating was included as a control of the probe.

\section{Cell protein content analysis}

Cell protein content was analysed by FCM using the fluorochrome fluorescein isothiocyanate (FITC), which emits green fluorescence $(525 \mathrm{~nm}$ ) when it is excited by the laser light of the cytometer $(488 \mathrm{~nm})$. This fluorochrome is reactive towards amine groups on proteins and remains attached to cells after washing due to the covalent nature of its binding (Shapiro 1995).

Since FITC is not able to diffuse across cell membranes, cells were permeabilised with the weak non-ionic detergent digitonin that associates with membrane sterols, creating pores (Elias

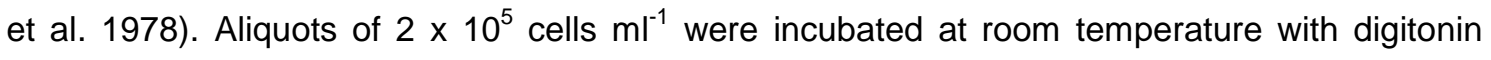
(final concentration: $32.54 \mu \mathrm{M}$ ), from a $3.25 \mathrm{mM}$ stock solution freshly prepared in DMSO, for 15 min. This pre-treatment was not seen to affect the cell autofluorescence. Stock solution of FITC (Sigma-Aldrich Co.) was freshly prepared at a concentration of $4 \mathrm{mM}$ in DMSO, and cell suspensions were stained with the appropriate volume of the fluorochrome stock (final concentration: $0.25 \mu \mathrm{M}$ ) for $35 \mathrm{~min}$ at room temperature and in darkness. FITC fluorescence was collected by FL1 detector (505-545 nm), and values obtained were corrected as in the case of ROS probes.

Data analysis

Mean and standard error values were calculated for each treatment from three independent replicate cultures. Data are given as mean values \pm standard error (S.E.) of the mean.To determine significant differences among test concentrations, data were statistically analysed by an overall one-way analysis of variance (ANOVA) using SPSS 16.0 software. A $p$-value $<0.05$ was considered statistically significant. When significant differences were observed, means were compared using the multiple-range Duncan test.

\section{Results}

\section{Paraquat concentrations}

Measured concentrations of paraquat at the beginning of the experiment were close to nominal values $(>90 \%)$, while at the end of the exposure period (96 h) the herbicide concentrations were drastically reduced, ranging from 8 to $17 \%$ of the initial nominal concentrations (Table 1 ).

Table 1 Nominal and measured concentrations of paraquat in Measured concentration (nM) culture samples collected during

concentration $(\mathrm{nM})$ 
the exposure period

\begin{tabular}{lrr}
\cline { 2 - 3 } & $0 \mathrm{~h}$ & $96 \mathrm{~h}$ \\
\hline 0 & $<\mathrm{LOD}^{\mathrm{a}}$ & $<\mathrm{LOD}$ \\
50 & $45.96 \pm 0.33$ & $3.76 \pm 0.13$ \\
100 & $95.30 \pm 0.95$ & $9.63 \pm 0.27$ \\
150 & $140.46 \pm 2.17$ & $19.45 \pm 0.01$ \\
200 & $190.99 \pm 0.37$ & $33.41 \pm 0.25$ \\
${ }^{\mathrm{a}}<$ LOD (limit of detection) of the lowest standard which was $1 \mathrm{nM}$
\end{tabular}

\section{Oxidative stress}

Since FCM allows us to assess the intercellular variability of the cell populations, detecting cell subpopulations with distinct features, as is the case, we could study the ROS level separately for chlorotic and non-chlorotic cells. After staining with $\mathrm{HE}$, a percentage of chlorotic cells were not stained (encircled subpopulation in Fig. 1b); these cells were not taken into account when performing the data analysis. Chlorotic cells, independently of the herbicide concentration in culture, showed ROS levels, both superoxide anion and hydrogen peroxide, similar to those observed in control culture cells (Fig. 2). Superoxide anion level in chlorotic cells of cultures exposed to the highest paraquat concentration assayed is even significantly lower $(p<0.05)$ than that showed by cells not exposed to the herbicide (Figs. 1a, b, 2a).

Analysis of non-chlorotic cells revealed a different behaviour, hence ROS levels increased in these cells after the exposure to paraquat (Fig. 1) in a concentrationdependent manner (Fig. 2). Superoxide anion level responded in a more sensitive way, since even cells exposed to the lowest herbicide concentration assayed, $50 \mathrm{nM}$, showed a significantly increased $(p<0.05)$ level of this radical (about $20 \%$ higher than control) (Fig. 2a).
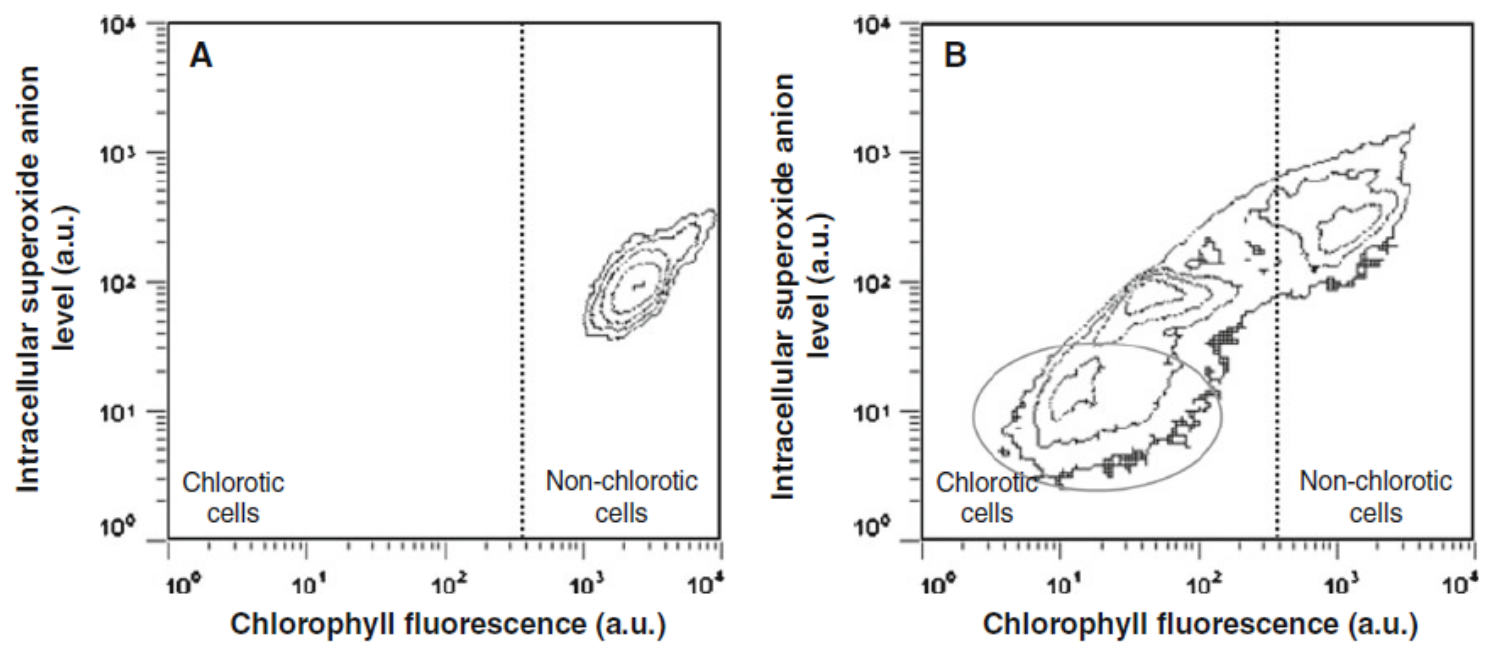

Fig. 1 Biparametric histograms showing the intracellular levels of superoxide anion $(a, b)$ and hydrogen peroxide (c, d), determined by FCM using the fluorochromes HE and DHR123 respectively, versus chlorophyll fluorescence, for control C. moewusii cultures $(\mathrm{a}, \mathrm{c})$ and cultures exposed to $200 \mathrm{nM}$ paraquat (b, d) after $96 \mathrm{~h}$ 

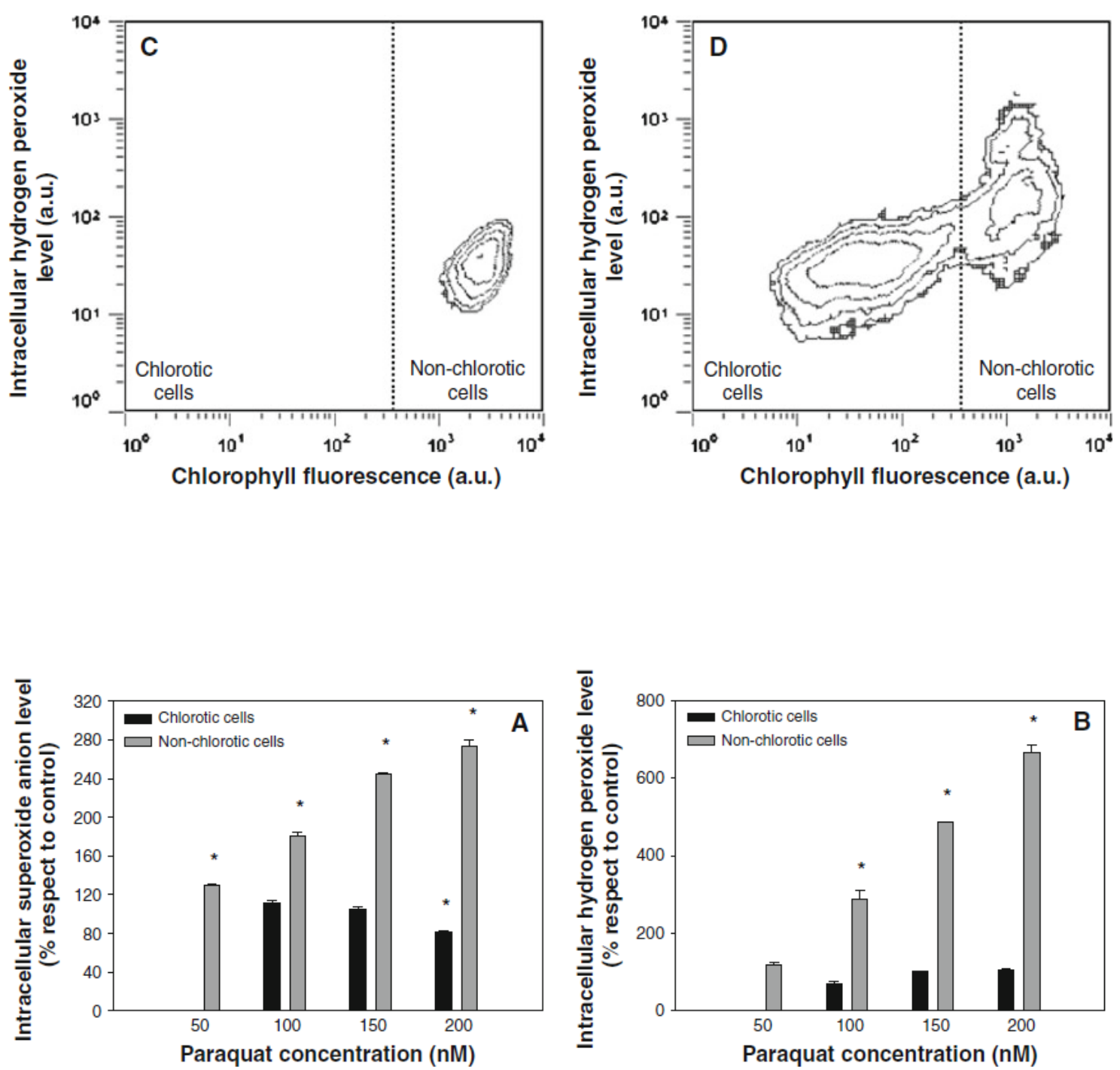

Fig. 2 ROS intracellular levels, superoxide anion (a) and hydrogen peroxide (b), determined by FCM using the fluorochromes HE and DHR123 respectively, for $C$. moewusii cultures after $96 \mathrm{~h}$ of exposure to different paraquat concentrations. Results represent the mean fluorescence intensities of the exposed cultures $(n=3)$, analyzing separately non-chlorotic and chlorotic cells when both were present, expressed as the percentage of the control. Asterisks indicate significant differences with respect to control $(p<0.05)$

\section{Cytoplasmic membrane potential}

The flow cytometric analysis of $\mathrm{DiBAC}_{4}(3)$-stained cells showed that paraquat affected cytoplasmic membrane potential of $C$. moewusii cells, leading to the depolarization of the plasma membrane, i.e. to a huge fluorochrome influx inside the cells (Fig. 3).

The possibility of separately analysing chlorotic and non-chlorotic cells allows us to observe that chlorotic cells, present in cultures exposed to paraquat concentrations above $50 \mathrm{nM}$ (Table 2), were cells with a depolarized cytoplasmic membrane, since they showed a $\mathrm{DiBAC}_{4}(3)$-derived fluorescence increased with respect to non-stressexposed cells (control) (Fig. 3). 
Excluding the chlorotic cells from the analysis, a concentration-dependent effect of the herbicide was observed,whose presence in culture in concentrations higher than $50 \mathrm{nM}$ induced the membrane depolarisation in a significant percentage of analysed cells $(p<0.05)$. In this way, between non-chlorotic cells in cultures exposed to $200 \mathrm{nM}$, merely $43.68 \%$ of the cells maintained a normal cytoplasmic membrane potential comparable to control cells (Table 2).
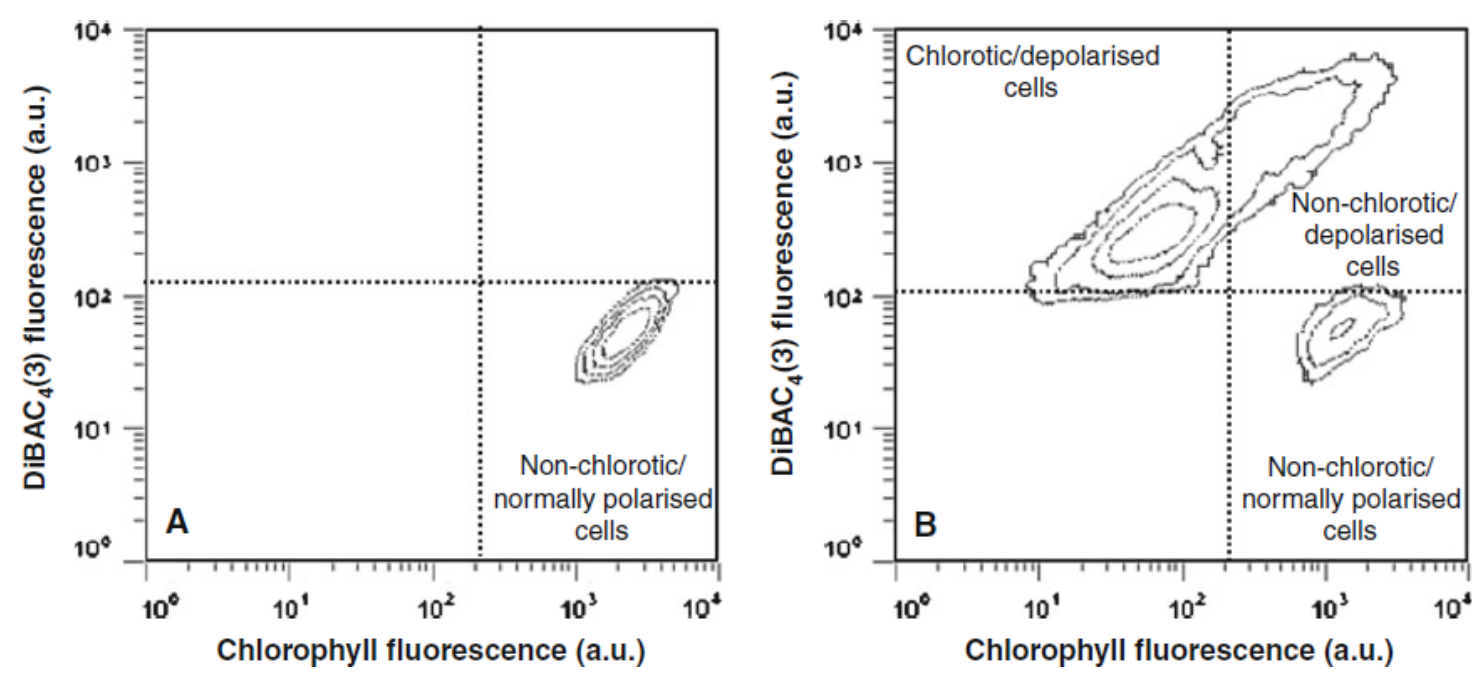

Fig. 3 Biparametric histograms showing the cytoplasmic membrane potential variation, as a function of changes in $\mathrm{DiBAC}_{4}(3)$ fluorescence exhibited by cells stained with this fluorochrome and determined by FCM, versus chlorophyll fluorescence, for control C. moewusii cultures (a) and cultures exposed to 200 $\mathrm{nM}$ paraquat (b) after $96 \mathrm{~h}$

Metabolic activity: FDA-derived fluorescence generation based on esterase activity level

The in fluxo analysis of the FDA-derived fluorescence generation, i.e. the esterase activity, in $C$. moewusii cells after exposure to increasing paraquat concentrations showed that chlorotic cells and a certain percentage of nonchlorotic cells, the higher the paraquat concentration, did not show a green fluorescence increase over time, related to fluorescein generation, after the addition of FDA, revealing its metabolically non-active state (Fig. 4; Table 2). In this way, esterase activity was only analysed on metabolically active non-chlorotic cells for each culture. The activity level of these cells was affected by paraquat in a concentration-dependent manner. It was already significantly reduced $(p<0.05)$ in cultures exposed to the lowest herbicide concentration and this reduction was more pronounced when paraquat concentration increased, thus it was reduced by half in cultures exposed to $200 \mathrm{nM}$ paraquat as compared to control cultures (Table 2). 
A

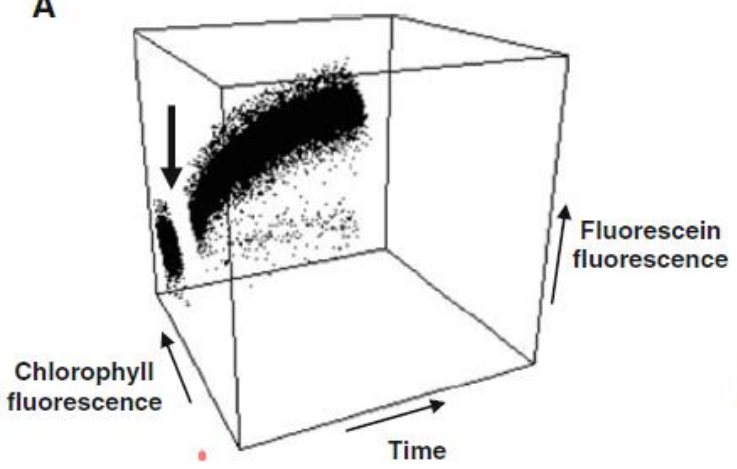

B

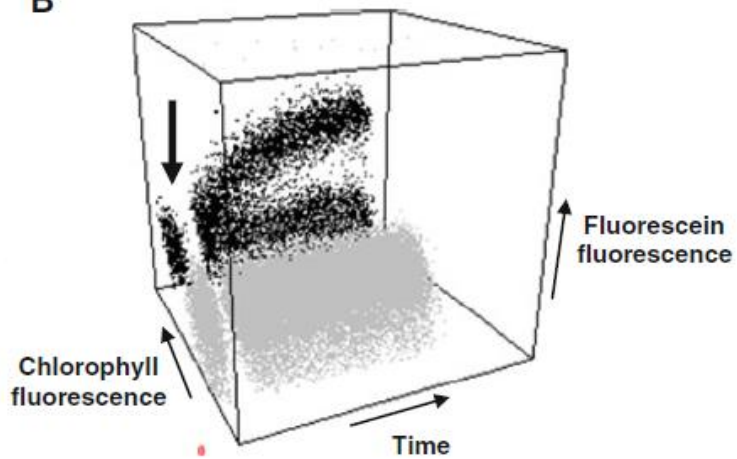

Fig. 4 Three-dimensional kinetic plots for $C$. moewusii cells, in response to staining with FDA, from control cultures (a) and cultures exposed to $200 \mathrm{nM}$ paraquat (b) over $96 \mathrm{~h}$ ( $\mathrm{X}$ axis: Time; $\mathrm{Y}$ axis: Fluorescein fluorescence; $Z$ axis: Chlorophyll fluorescence). The increase of FDA-derived fluorescein fluorescence in function of time is shown for chlorotic (grey) and non-chlorotic (black) cells. The arrow indicates the time of addition of FDA to unstained microalgal suspensions

\section{Cell protein content}

The possibility of studying chlorotic and non-chlorotic cells separately allows us to observe that these cell types showed differences in their biochemical composition.

The flow cytometric analysis of FITC-stained cells revealed that non-chlorotic cells, regardless of paraquat concentration, did not show significant differences respect to control with regard to their protein content, showing even a slight increase in cultures exposed to $100 \mathrm{nM}$ of paraquat (Fig. 6). However, chlorotic cells, present in cultures with a paraquat concentration of $100 \mathrm{nM}$ or higher, showed a cell protein content which was significantly lower than the values obtained for non-chlorotic cells of their respective culture, and therefore significantly reduced with respect to control cells $(p<0.05)$ (Figs. 5, 6).

Protein content shown by chlorotic cells did not reveal significant differences between paraquat treatments (Fig. 6).
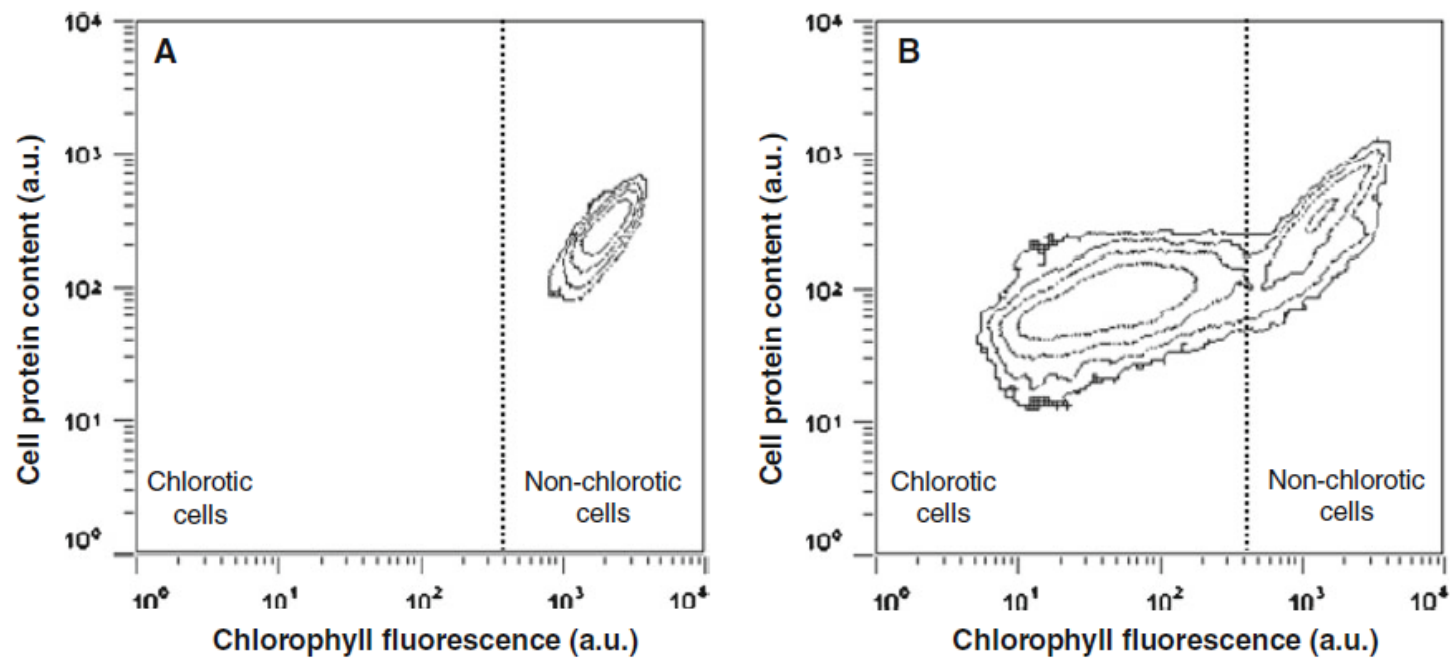
Fig. 5 Biparametric histograms showing the cell protein content, determined by FCM using the fluorochrome FITC, versus chlorophyll fluorescence, for control C. moewusii cultures (a) and cultures exposed to $200 \mathrm{nM}$ paraquat (b) after $96 \mathrm{~h}$

Fig. 6 Cell protein content, determined by FCM using the fluorochrome FITC, for $C$. moewusii cultures after $96 \mathrm{~h}$ of exposure to different paraquat concentrations. Results represent the mean fluorescence intensities for the different cultures $(n=3)$, analyzing separately non-chlorotic and chlorotic cells when both were present. Asterisks indicate significant differences with respect to control $(p<0.05)$

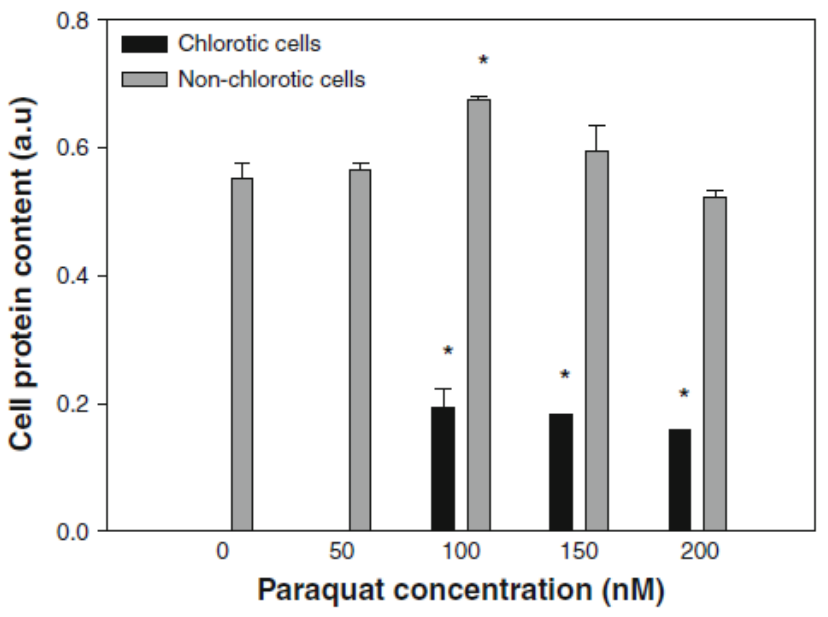

\section{Discussion}

Intensive applications of herbicides for weed control have attracted great concerns from the public since pollution with these chemicals has been reported as a potential risk for aquatic ecosystems as well as for the quality of drinking water (AbdEl-Aty and El-Dib 2009; Katsumata et al. 2006). In ecotoxicological risk assessment, standard bioassays are used to assess the toxicity of pollutants as herbicides on aquatic organisms such as microalgae. These are among the essential components of aquatic systems so that chemical effects can provoke structural and functional alterations in these ecosystems. Paraquat is a herbicide with a well-known mode of action that can have potentially adverse effects on primary producers. A number of studies on the effects of this herbicide on microalgae have been carried out using traditional toxicity endpoints (Ibrahim 1990; Oliveira et al. 2007; Sáenz et al. 1997; Wong 2000), but only a few studies have focused on the effects on other levels of biological organisations or have attempted to detect underlying mechanisms of toxicity (Franqueira et al. 1999; Jamers and De Coen 2010; Prado et al. 2009a). In the present work, the effects of paraquat, in environmentally relevant concentrations (Bacchetta et al. 2002; Cochón et al. 2007; Eisler 1990), were investigated on the green alga $C$. moewusii using alternative parameters to the traditional endpoints, through the optimisation of different FCM assays which allowed us to characterise the microalgal response assessing the toxic effects on algal physiology at cellular level.

ROS such as $\mathrm{O}^{*}, \mathrm{H}_{2} \mathrm{O}_{2}$ or $\mathrm{OH}^{*}$ are constantly generated in cells as byproducts via various oxygen metabolisms predominantly in chloroplasts, mitochondria and peroxisomes (Apel and Hirt 2004). Under normal conditions, ROS production is well controlled by cell antioxidant systems, but it is known that a range of abiotic and biotic stresses induce the excessive generation of ROS in plants due to perturbations of chloroplastic and mitochondrial metabolism, 
exceeding the capacity of ROS-scavenging reactions (Ananieva et al. 2004; Liu et al. 2009; Taylor et al. 2002). Paraquat has been reported to be a potent redox-cycling chemical agent (Bus and Gibson 1984; Jung and Kim 2003) that acts by intercepting electrons from the photosynthetic electron transport chain at photosystem I level. This results in the production of bipyridyl radicals that readily react with $\mathrm{O}_{2}$ to produce $\mathrm{O}_{2}{ }^{-}$and then, through a series of reactions, produce $\mathrm{H}_{2} \mathrm{O}_{2}$ and $\mathrm{OH}^{\circ}$, when the herbicide molecule is regenerated (Ananieva et al. 2002).

Production of ROS is a major cause which subsequently damages the plant cells (Ekmekci and Terzioglu 2005; Taylor et al. 2002) and therefore paraquat phytotoxicity may be associated with oxidative stress-mediated mechanisms (Suntres 2002).

Results obtained in the present study confirm the expectations, based on the increased intracellular levels of $\mathrm{O}_{2}{ }^{--}$and $\mathrm{H}_{2} \mathrm{O}_{2}$ observed in cultures treated with paraquat when nonchlorotic cells are analysed (Fig. 2). This response was observed for cells exposed to the lowest paraquat concentration assayed, $50 \mathrm{nM}$, when intracellular level of $\mathrm{O}_{2}^{--}$was analysed. However there was not a significant increase of $\mathrm{H}_{2} \mathrm{O}_{2}$ level in such cells with respect to control $(p<0.05)$ (Fig. 2). This differential response may be associated to the paraquat mechanism of action itself, which continuously yields $\mathrm{O}_{2}{ }^{--}$by means of repeated redox cycles. The high oxygen concentration of the chloroplast ensures the rapid re-oxidation of paraquat radicals, which regenerates paraquat and promotes continuous formation of $\mathrm{O}_{2}{ }^{\circ-}$ (Ekmekci and Terzioglu 2005), so it is possible that antioxidant systems which keep the intracellular level of this agent under control in normal circumstances, such as superoxide dismutase enzymes, were not able to detoxify this toxic radical produced at such a high rate. Excess $\mathrm{O}_{2}{ }^{--}$results in the production of $\mathrm{H}_{2} \mathrm{O}_{2}$ by spontaneous or enzymatic dismutation (Perl-Treves and Perl 2002), although intracellular levels of this agent in cultures exposed to the lowest paraquat concentration did not show differences with respect to control (Fig. 2b), which may be related to cell antioxidant mechanisms still capable of tackling the overproduction of this ROS. It has been reported that certain paraquat concentrations induce antioxidant mechanisms, both enzymatic and nonenzymatic, in plant and animal cells (Ananieva et al. 2004; Cochón et al. 2007; Liu et al. 2009; Mussi and Calcaterra 2010; Qian et al. 2009). However, the antioxidant capacity of cells may be overwhelmed after the exposure to high herbicide concentration. This could explain the increase of intracellular ROS levels in cultures exposed to a paraquat concentration above $50 \mathrm{nM}$ (Fig. 2), especially in the case of $\mathrm{H}_{2} \mathrm{O}_{2}$ whose level in non-chlorotic cells exposed to $200 \mathrm{nM}$ was approximately seven times the level shown by control cells (Fig. 2b).

Chlorotic cells however, showed ROS levels similar to those observed in control cells or even lower (Figs. 1, 2), which can be related to the results obtained in the esterase activity assay that showed the metabolically non-active state of these cells (Fig. 4). ROS production would stop in these cells, at the time that these radicals were being consumed in oxidation reactions with cell 
components as its chlorosis level indicates. A similar response has been reported for Chlamydomonas reinhardtii exposed to osmotic stress, suggesting that cells in which ROS generation was not accelerated were completely dead cells (Yoshida et al. 2004). There was a certain percentage of chlorotic cells that were not stained (encircled subpopulation in Fig. 1b), probably due to a high genotoxic effect of paraquat on these cells (Prado et al. 2009a) so that they can not retain the DNA-binding fluorochrome.

In the case of microorganisms such as microalgae, the plasma membrane is the chemiosmotic barrier that provides the interface between the organism and its external environment. Across this phospholipid bilayer, a transmembrane electrochemical potential (negative inside) plays a pivotal role in the control of solute exchange, with the implication of large gradients between intracellular and extracellular concentrations of a variety of ions. It is an energy-requiring disequilibrium whose maintenance depends on the action of different channels and pumps (Lloyd et al. 2004). Therefore, the cytoplasmic membrane potential will report on the current transport and energy status of the cell (Konrad and Hedrich 2008). Perturbations of the cytoplasmic membrane potential provide a sensitive and rapid indication of physicochemical changes in the extracellular environment and therefore have been suggested to be mediators of subsequent physiological cellular responses (Rabinovitch and June 1990) to environmental stress factors. Results obtained in this study showed that the herbicide paraquat induces the plasma membrane depolarisation in a part of the microalgal population analysed (Fig. 3; Table 2). It was observed that chlorotic cells were characterised by their membrane depolarisation, since they showed an increased $\mathrm{DiBAC}_{4}(3)$-derived fluorescence as compared to control cells (Fig. 3). This could be related to results obtained in a previous study where we concluded that these cells were non-viable (Prado et al. 2011). Taking only the non-chlorotic cells into account, we could observe that the percentage of cells maintaining a membrane potential decreased in a concentration-dependent manner (Table 2), similar to the decrease of viable/active cells observed in a previous study (Prado et al. 2011). In this way, the cytoplasmic membrane depolarisation of $C$. moewusii cells after $96 \mathrm{~h}$ of paraquat exposure could be considered an indicator of the non-viability of these cells, and these effects can be associated with membrane alterations provoked by the peroxidation of membrane lipids as a consequence of ROS attack. Since the plasma membrane potential is a physiological parameter dependent both upon cellular metabolism and the integrity of the cell membrane (Scott and Rabito 1988), only metabolically active cells whose membranes have not been damaged are capable of generating and maintaining a normal membrane potential (Jepras et al. 1997). In fact, the membrane potential probe $\mathrm{DiBAC}_{4}(3)$ was reported to be a sensitive and robust cell viability indicator (Ben Amor et al. 2002; Jepras et al. 1995; Lloyd and Hayes 1995; Papadimitriou et al. 2006).

Table 2 Non-chlorotic cell analysis of cytoplasmic membrane potential and esterase activity by FCM, using the fluorochromes $\mathrm{DiBAC}_{4}(3)$ and $\mathrm{FDA}$ respectively, for $C$. moewusii cultures exposed to different paraquat concentrations over $96 \mathrm{~h}$ 


\begin{tabular}{|c|c|c|c|c|}
\hline \multirow{2}{*}{$\begin{array}{l}\text { Paraquat } \\
\text { concentration } \\
\text { (nM) }\end{array}$} & \multirow{2}{*}{$\begin{array}{l}\text { Non-chlorotic } \\
\text { cells (\%) }\end{array}$} & \multicolumn{3}{|l|}{ Non-chlorotic cells } \\
\hline & & $\begin{array}{l}\text { Normally polarised } \\
\text { cells (\%) }\end{array}$ & $\begin{array}{l}\text { Metabolically } \\
\text { active cells (\%) }\end{array}$ & $\begin{array}{l}\text { Esterase activity } \\
\text { (\% respect to control) }\end{array}$ \\
\hline 0 & $100,00 \pm 0,00$ & $98,90 \pm 0,05$ & $99,39 \pm 0,03$ & $100 \pm 0,57$ \\
\hline 50 & $100,00 \pm 0,00$ & $97,93 \pm 0,27$ & $98,54 \pm 0,09$ & $91,96 \pm 0,99^{*}$ \\
\hline 100 & $80,12 \pm 0,47^{\star}$ & $83,62 \pm 1,79^{*}$ & $90,33 \pm 0,77^{*}$ & $73,22 \pm 0,27^{*}$ \\
\hline 150 & $47,85 \pm 0,23^{\star}$ & $59,09 \pm 1,10^{*}$ & $64,29 \pm 3,62^{*}$ & $65,46 \pm 4,47^{*}$ \\
\hline 200 & $16,59 \pm 0,34^{*}$ & $43,68 \pm 0,86^{*}$ & $43,46 \pm 0,76^{*}$ & $55,98 \pm 0,95^{*}$ \\
\hline
\end{tabular}

Enzyme inhibition measurements in microalgae are becoming increasingly popular indicators of environmental stress because they offer a rapid and sensitive endpoint (Blaise and Ménard 1998; Peterson and Stauber 1996). In particular, esterases comprise a key group of ubiquitous enzymes in plants and animals which have been shown to relate well to metabolic activity and cell viability (Dorsey et al. 1989; Gala and Giesy 1990). Esterase activity has been used as a sensitive endpoint in different toxicity tests with microalgae, proving to be a reliable indicator of the toxic effects of pollutants (Hadjoudja et al. 2009; Jamers et al. 2009; Lage et al. 2001; Yu et al. 2007). A decline in enzyme activity is usually considered indicative of the presence of stress (Franklin et al. 2001; Regel et al. 2002). As well as the increase of the percentage of non-active cells (chlorotic cells and a concentration-dependent percentage of non-chlorotic cells), paraquat induced a decrease of the esterase activity level in metabolically active non-clorotic cells in a concentration- dependent manner (Table 2). It is possible that the overproduction of ROS caused oxidative modifications in protein structure and led to alterations in enzyme function, which could explain the results of protein content analysis by flow cytometry. Protein content in non-chlorotic cells was not negatively affected by the paraquat concentrations assayed (Figs. 5, 6 ), but much of this protein pool is likely to be non-functional. One of the most common oxidative modifications of proteins is carbonylation (Valavanidis et al. 2006), which alters protein activity and increases its susceptibility to proteolytic attack (Pena et al. 2006).

Non-chlorotic cells in cultures exposed to $100 \mathrm{nM}$ showed a slight increase in its protein content (Fig. 6). This could be related to a detoxification mechanism (Rioboo et al. 2002). Chlorotic cells however showed a drastically decreased protein content (Figs. 5, 6), probably as a consequence of a strong degradation by oxygen radicals (Davies 1987), which may be considered as another indicator of the non-viability of these cells (Darzynkiewicz et al. 1992). This protein content reduction may also be related to the negative effect of paraquat on enzyme activities involved in nitrogen assimilation (Prado et al. 2009b).

\section{Conclusions}

Flow cytometry allowed the screening of new toxicity endpoints, at cellular level, for improving the bioassessment of pollutant toxicity. It is a fast excellent means of obtaining information 
about the physiological status and metabolism of microalgal cells after exposure to an environmental stress, which makes it a useful tool for biological monitoring of water quality. In view of the obtained results, we have concluded that a range of significant physiological alterations, detected by flow cytometry, occur when the microalga C. moewusii is challenged with environmentally relevant concentrations of the herbicide paraquat. Chlorotic cells are those that have been poisoned and are either dying or dead; the experimental results confirm this and provide some characterisation of mechanisms. Toxic effects on this organism, as a ubiquitous microalga (primary producer) in freshwater environments, can potentially have profound effects in structure and function of these ecosystems.

\section{Acknowledgments}

This work was supported by research project from the Spanish Government's Ministerio de Educación e Innovación (CGL2004-02037). R. Prado gratefully acknowledges a F.P.U. fellowship from the Spanish Ministerio de Educación y Ciencia. The authors wish to thank Gerardo Fernández (SAI-UDC) his willingness to carry out the determination of paraquat in water, and also thank the suggestions made by reviewers to improve this article.

\section{References}

1. AbdEl-Aty AM, El-Dib MA (2009) Uptake and the effects of cyanazine on Scenedesmus obliquus and Anabaena flos-aquae. Desalination 249:1294-1297

2. Adler NE, Schmitt-Jansen M, Altenburger R (2007) Flow cytometry as a tool to study phytotoxic modes of action. Environ Toxicol Chem 26:297-306

3. Agustí S, Satta MP, Mura MP, Benavent E (1998) Dissolved esterase activity as a tracer of phytoplankton lysis: evidence of high phytoplankton lysis rates in the northwestern Mediterranean. Limnol Oceanogr 43:1836-1849

4. Ananieva EA, Alexieva VS, Popova LP (2002) Treatment with salicylic acid decreases the effects of paraquat on photosynthesis. J Plant Physiol 159:685-693

5. Ananieva EA, Christov KN, Popova LP (2004) Exogenous treatment with salicylic acid leads to increased antioxidant capacity in leaves of barley plants exposed to paraquat. J Plant Physiol 161:319-328

6. Apel K, Hirt H (2004) Reactive oxygen species: metabolism, oxidative stress, and signal transduction. Ann Rev Plant Biol 55:373-399

7. Bacchetta R, Manteca P, Vailati G (2002) Oocyte degeneration and altered ovipository activity induced by paraquat in the freshwater snail Physa fontinalis (Gastropoda: Pulmonata). J Moll Stud 68:181-186

8. Ben Amor K, Breeuwer P, Verbaarschoot P, Rombouts FM, Akkermans ADL, De Vos WM, Abee T (2002) Multiparametric flow cytometry and cell sorting for the assessment of viable, injured, and dead bifidobacterium cells during bile sat stress. Appl Environ Microbiol 68:5209-5216

9. Benov L, Sztejnberg L, Fridovich I (1998) Critical evaluation of the use of hydroethidine as a measure of superoxide anion radical. Free Radical Biol Med 25:826-831

10. Blaise C, Ménard L (1998) A micro-algal solid phase test to assess the toxic potential of freshwater sediments. Water Qual Res J Can 33:133-151

11. Brown TE, Richardson FL, Vaughn ML (1967) Development of red pigmentation in Chlorococcum wimmeri (Chlorophyta: Chlorococcales). Phycologia 6:167-184

12. Bus JS, Gibson JE (1984) Paraquat: model for oxidant-initiated toxicity. Environ Health Perspect 55:37-46

13. Castro R, Moyano E, Galceran MT (1999) Ion-pair liquid chromatography-atmospheric pressure ionization mass spectrometry for the determination of quaternary ammonium herbicides. J Chromatogr A 830:145-154 
14. Caux P-Y, Ménard L, Kent RA (1996) Comparative study of the effects of MCPA, butylate, atrazine, and cyanazine on Selenastrum capricornutum. Environ Pollut 92:219-225

15. Cid A, Fidalgo P, Herrero C, Abalde J (1996) Toxic action of copper on the membrane system of a marine diatom measured by flow cytometry. Cytometry 25:32-36

16. Cochón AC, Della Penna AB, Kristoff G, Piol MN, Martín San, de Viale LC, Verrengia Guerrero NR (2007) Differential effects of paraquat on oxidative stress parameters and poliamine levels in two freshwater invertebrates. Ecotoxicol Environ Saf 68:286-292

17. Daam MA, Rodrigues AMF, Van den Brink PJ, Nogueira AJA (2009) Ecological effects of the herbicide linuron in tropical freshwater microcosms. Ecotoxicol Environ Saf 72:410-423

18. Darzynkiewicz Z, Bruno S, Del Bino G, Gorczyca W, Hotz MA, Lassota P, Traganos F (1992) Features of apoptotic cells measured by flow cytometry. Cytometry 13:795-808

19. Davies KJA (1987) Protein damage and degradation by oxygen radicals. I. General aspects. J Biochem Chem 262:9895-9901

20. De Lorenzo ME, Taylor LA, Lund SA, Pennington PL, Strozier ED, Fulton MH (2002) Toxicity and bioconcentration potential of the agricultural pesticide endosulfan in phytoplankton and zooplankton. Arch Environ Contam Toxicol 42:173-181

21. Deneer JW (2000) Toxicity of mixtures of pesticides in aquatic systems. Pest Manag Sci 56:516-520

22. Dikshit M, Sharma $P$ (2001) Nitric oxide mediated modulation of free radical generation response in the rat polymorphonuclear leukocytes: a flow cytometric study. Methods Cell Sci 24:69-76

23. Dorsey J, Yentsch CM, Mayo S, McKenna C (1989) Rapid analytical technique for the assessment of cell metabolic activity in marine microalgae. Cytometry 10:622-628

24. Ehrenberg B, Montana V, Wei MD, Wuskell JP, Loew LM (1988) Membrane potential can be determined in individual cells from the Nernstian distribution of cationic dyes. Biophys J 53:785-794

25. Eisler R (1990) Paraquat hazards to fish, wildlife, and invertebrates: a synoptic review. Contaminant Hazard Reviews. US Fish Wild Serv Biol Rep 85(1.22):28

26. Ekmekci Y, Terzioglu S (2005) Effects of oxidative stress induced by paraquat on wild and cultivated wheats. Pestic Biochem Physiol 83:69-81

27. Elias PM, Goerke J, Friend DS (1978) Freeze-fracture identification of sterole-digitonin complexes in cell and liposome membranes. J Cell Biol 78:577-596

28. Eullaffroy P, Vernet G (2003) The F684/F735 chlorophyll fluorescence ratio: a potential tool for rapid detection and determination of herbicide phytotoxicity in algae. Water Res 37:1983-1990

29. Franklin NM, Adams MS, Stauber JL, Lim RP (2001) Development of an improved rapid enzyme inhibition bioassay with marine and freshwater microalgae using flow cytometry. Arch Environ Contam Toxicol 40:469-480

30. Franqueira D, Cid A, Torres E, Orosa M, Herrero C (1999) A comparison of the relative sensitivity of structural and functional cellular responses in the alga Chlamydomonas eugametos exposed to the herbicide paraquat. Arch Environ Contam Toxicol 36:264-269

31. Franqueira D, Orosa M, Torres E, Herrero C, Cid A (2000) Potential use of flow cytometry in toxicity studies with microalgae. Sci Total Environ 247:119-126

32. Fuerst EP, Vaughn KC (1990) Mechanisms of paraquat resistance. Weed Technol 4:150-156

33. Gala W, Giesy JP (1990) Flow cytometric techniques to assess toxicity to algae. In: Landis WG, van der Schalie WH (eds) Aquatic toxicology and risk assessment, thirteenth volume. ASTM TP 1096. American Society for Testing and Materials, Philadelphia, pp 237-246

34. Gilbert F, Galgani F, Cadiou Y (1992) Rapid assessment of metabolic activity in marine microalgae: application in ecotoxicological tests and evaluation of water quality. Mar Biol 112:199-205

35. Hadjoudja S, Vignoles C, Delucht V, Lenain JF, Le Jeune AH, Baudu M (2009) Short term copper toxicity on Microcystis aeruginosa andChlorella vulgaris using flow cytometry. Aquat Toxicol 94:255264

36. Henderson LM, Chappell JB (1993) Dihydrorhodamine 123: a fluorescent probe for superoxide generation? Eur J Biochem 217:973-980

37. Ibrahim EA (1990) The influence of the herbicide paraquat "gramoxon" on growth and metabolic activity of three chlorophytes. Water Air Soil Pollut 51:89-93

38. Jamers A, De Coen W (2010) Effect assessment of the herbicide paraquat on a green alga using differential gene expression and biochemical biomarkers. Environ Toxicol Chem 29:893-901

39. Jamers A, Lenjou M, Deraedt P, Van Bockstaele D, Blust R, de Coen W (2009) Flow cytometryc analysis of the cadmium-exposed green algaChlamydomonas reinhardtii (Chlorophyceae). Eur $\mathrm{J}$ Phycol 44:541-550 
40. Jepras RI, Carter J, Pearson SC, Paul FE, Wilkinson MJ (1995) Development of a robust flow cytometric assay for determining numbers of viable bacteria. Appl Environ Microbiol 61:2696-2701

41. Jepras RI, Paul FE, Pearson SC, Wilkinson MJ (1997) Rapid assessment of antibiotic effects on Escherichia coli by bis-(1, 3-dibutylbarbituric acid) trimethine oxonol and flow cytometry. Antimicrob Agents Chemother 41:2001-2005

42. Jochem FJ (1999) Dark survival strategies in marine phytoplankton assessed by cytometric measurement of metabolic activity with fluorescein diacetate. Mar Biol 135:721-728

43. Juan G, Cavazzoni M, Sáez GT, O’Connor J-E (1994) A fast kinetic method for assessing mitochondrial membrane potential in isolated hepatocytes with rhodamine 123 and flow cytometry. Cytometry 15:335-342

44. Jung IL, Kim IG (2003) Thiamine protects against paraquat-induced damage: scavenging activity of reactive oxygen species. Environ Toxicol Pharmacol 15:19-26

45. Katsumata H, Kaneco S, Suzuki T, Ohta K (2006) Determination of atrazine and simazine in water samples by high-performance liquid chromatography after preconcentration with heat-treated diatomaceous earth. Anal Chim Acta 577:214-219

46. Kish PA (2006) Evaluation of herbicide impact on periphyton community structure using the Matlock periphytometer. J Freshwater Ecol 21:341-348

47. Konrad KR, Hedrich R (2008) The use of voltage-sensitive dyes to monitor signal-induced changes in membrane potential-ABA triggered membrane depolarization in guard cells. Plant J 55:161-173

48. Kuin $H$, Koerten $H$, Ghijsen WEJM, Munnik $T$, van den Ende $H$, Musgrave $A$ (2000) Chlamydomonas contains calcium stores that are mobilized when phospholipase $C$ is activated. Planta 210:286-294

49. Lage OM, Sansonetty F, O'Connor J-E, Parente AM (2001) Flow cytometric analysis of chronic and acute toxicity of copper (II) on the marine dinoflagellate Amphidinium carterae. Cytometry 44:226235

50. Liu Z, Zhang X, Bai J, Suo B, Xu P, Wang L (2009) Exogenous paraquat changes antioxidant enzyme activities and lipid peroxidation in drought-stressed cucumber leaves. Sci Hortic 121:138-143

51. Lloyd D, Hayes AJ (1995) Vigour, vitality and viability of microorganisms. FEMS Microbiol Lett 133:17

52. Lloyd D, Harris JC, Biagini GA, Hughes MR, Maroulis S, Bernard C, Wadley RB, Edwards MR (2004) The plasma membrane of microaerophilic protists: oxidative and nitrosative stress. Microbiology 150:1183-1190

53. Muller R, Schreiber U, Escher BI, Quayle P, Bengtson Nash SM, Mueller JF (2008) Rapid exposure assessment of PSII herbicides in surface water using a novel chlorophyll a fluorescence imaging assay. Sci Total Environ 401:51-59

54. Mussi MA, Calcaterra NB (2010) Paraquat-induced oxidative stress response during amphibian early embryonic development. Comp Biochem Physiol Part C 151:240-247

55. Nguyen-Ngoc H, Durrieu C, Tran-Minh C (2009) Synchronous-scan fluorescence of algal cells for toxicity assessment of heavy metals and herbicides. Ecotoxicol Environ Saf 72:316-320

56. Oliveira JB, Goncalves AMM, Goncalves F, Pereira MJ (2007) Growth inhibition of algae exposed to paraquat. Fresenius Environ Bull 16:621-625

57. Papadimitriou K, Pratsinis H, Nebe-von-Caron G, Kletsas D, Tsakalidou E (2006) Rapid assessment of the physiological status of Streptococcus macedonicus by flow cytometry and fluorescent probes. Int J Food Microbiol 111:197-205

58. Pena L, Pasquini L, Tomaro ML, Gallego SM (2006) Proteolytic system in sunflower (Helianthus annuus L.) leaves under cadmium stress. Plant Sci 171:531-537

59. Perl-Treves R, Perl A (2002) Oxidative stress: an introduction. In: Inzé D, Van Montagu M (eds) Oxidative Stress in Plants. Taylor \& Francis, London, pp 1-32

60. Peterson SM, Stauber JL (1996) New algal enzyme bioassay for the rapid assessment of aquatic toxicity. Bull Environ Contam Toxicol 56:750-757

61. Plásek J, Sigler K (1996) Slow fluorescent indicators of membrane potential: a survey of different approaches to probe response analysis. J Photochem Photobiol B 33:101-124

62. Prado R, García R, Rioboo C, Herrero C, Abalde J, Cid A (2009a) Comparison of the sensitivity of different toxicity test endpoints in a microalga exposed to the herbicide paraquat. Environ Int 35:240247

63. Prado R, Rioboo C, Herrero C, Cid A (2009b) The herbicide paraquat induces alterations in the elemental and biochemical composition of non-target microalgal species. Chemosphere 76:14401444 
64. Prado R, Rioboo C, Herrero C, Cid A (2011) Characteriztion of cell response in Chlamydomonas moewusii cultures exposed to the herbicide paraquat: Induction of chlorosis. Aquat Toxicol 102:10-17

65. Qian H, Chen W, Sun L, Jin Y, Liu W, Fu Z (2009) Inhibitory effects of paraquat on photosynthesis and response to oxidative stress in Chlorella vulgaris. Ecotoxicology 18:537-543

66. Qin Y, Lu M, Gong X (2008) Dihydrorhodamine 123 is superior to 2, 7-dichlorodihydrofluorescein diacetate and dihydrorhodamine $6 \mathrm{G}$ in detecting intracellular hydrogen peroxide in tumor cells. Cell Biol Int 32:224-228

67. Rabinovitch PS, June $\mathrm{CH}$ (1990) Intracellular ionized calcium, membrane potential, and $\mathrm{pH}$. In: Ormerod MG (ed) Flow cytometry, a practical approach. Oxford University Press, Oxford, pp 161-185

68. Regel RH, Ferris JM, Ganf GG, Broookes JD (2002) Algal esterase activity as a biomeasure of environmental degradation in a freshwater creek. Aquat Toxicol 59:209-223

69. Rioboo C, González O, Herrero C, Cid A (2002) Physiological response of freshwater microalga (Chlorella vulgaris) to triazine and phenylurea herbicides. Aquat Toxicol 59:225-235

70. Rioboo C, Prado R, Herrero C, Cid A (2007) Population growth study of the rotifer Brachionus sp. fed with triazine-exposed microalgae. Aquat Toxicol 83:247-253

71. Rioboo C, O'Connor JE, Prado R, Herrero C, Cid A (2009) Cell proliferation alterations in Chlorella cells under stress conditions. Aquat Toxicol 94:229-237

72. Sáenz ME, Alberdi JL, Di Marzio WD, Accorinti J, Tortorelli MC (1997) Paraquat toxicity to different green algae. Bull Environ Contam Toxicol 58:922-928

73. Scott JA, Rabito CA (1988) Oxygen radicals and plasma membrane potential. Free Radical Biol Med 5:237-246

74. Seguin F, Druart JC, Le Cohu R (2001) Effects of atrazine and nicosulfuron on periphytic diatom communities in freshwater outdoor lentic mesocosms. Ann Limnol 37:3-8

75. Shapiro HM (1995) Practical Flow Cytometry, 3rd edn. Wiley-Liss Inc., New York

76. Suntres ZE (2002) Role of antioxidants in paraquat toxicity. Toxicology 180:65-77

77. Taylor NL, Day DA, Millar AH (2002) Environmental stress causes oxidative damage to plant mitochondria leading to inhibition of glycine decarboxylase. J Biol Chem 277:42663-42668

78. Valavanidis A, Vlahogianni T, Dassenakis M, Scoullos M (2006) Molecular biomarkers of oxidative stress in aquatic organisms in relation to toxic environmental pollutants. Ecotoxicol Environ Saf 64:178-189

79. van Wezel AP, van Vlaardingen $P$ (2004) Environmental risk limits for antifouling substances. Aquat Toxicol 66:427-444

80. Veal DA, Deere D, Ferrari B, Piper J, Attfield PV (2000) Fluorescence staining and flow cytometry for monitoring microbial cells. J Inmunol Methods 243:191-210

81. Walrand S, Valeix S, Rodríguez C, Ligot P, Chassagne J, Vasson M (2003) Flow cytometry study of polymorphonuclear neutrophil oxidative burst: a comparison of three fluorescent probes. Clin Chim Acta 331:103-110

82. Warren N, Allan IJ, Carter JE, House WA, Parker A (2003) Pesticides and other microorganic contaminants in freshwater sedimentary environments-A review. Appl Geochem 18:159-194

83. Wolff C, Fuks B, Chatelain P (2003) Comparative study of membrane potential-sensitive fluorescent probes and their use in ion channel screening assays. J Biomol Screen 8:533-543

84. Wong PK (2000) Effects of 2, 4-D, glyphosate and paraquat on growth, photosynthesis and chlorophyll-a synthesis of Scenedesmus quadricauda Berb 614. Chemosphere 41:177-182

85. Yoshida K, Igarashi E, Wakatsuki E, Miyamoto K, Hirata K (2004) Mitigation of osmotic and salt stresses by abscisic acid through reduction of stress-derived oxidative damage in Chlamydomonas reinhardtii. Plant Sci 167:1335-1341

86. Yu Y, Kong F, Wang M, Qian L, Shi X (2007) Determination of short-term copper toxicity in a multispecies microalgal population using flow cytometry. Ecotoxicol Environ Saf 66:49-56

87. Zhao H, Kalivendi S, Zhang H, Joseph J, Nithipatikom k, Vásquez-Vivar J, Kalyanaraman B (2003) Superoxide reacts with hydroethidine but forms a fluorescent product that is distinctly different from ethidium: potential implications in intracellular fluorescence detection of superoxide. Free Radical Biol Med 34:1359-1368 